\title{
インドネシャにおける地すべり予知の数例について
}

藤 原 明 敏*

\section{Some Examples of the Landslide Prediction in Indonesia} by Akitoshi FUJIWARA

\section{§1.はじめに}

インドネシャ国，わが国同様四周を海に囲まれた多島 国であり, 四-1に示すようにジャワ島, スマトラ島, ボ ルネオ島, セレベス島の四大島ならびに無数の小島から 構成されている。

今回の調查対象であるジャワ島は, 西端から東端まで 約 $1,000 \mathrm{~km}$, 幅 $150 \mathrm{~km}$ の東西に長い火山島であり, 西側 からゲデ山, スラメト山, スメル山等, 標高 $3,000 \mathrm{~m}$ 以 上の火山がほぼ一直線に点々と分布し, 過去の断層, そ の他構造線に沿ら火成活動の存在を示している。

ジャワ島を構成する地質は, 前述の要因によって図-2 に示すよらに，そのほとんどが火山に起因する火山灰， ならびに火山岩等の火山堆樻物 (Volcanic sediments), およびそれらが侵食されて 2 次的に堆㮴した河床堆積物 (River deposits) からなり, 標高 1,500〜3,700m の急 骖山地と, 標高300〜 400 m程度の緩やかな火山性台地が 形成されており，この中を緩勾配河川が Meander しな がら緩やかに流下している。

このような火山性台地内を当初西流し, 支川と合流し てほぼ北東へ流路を変更するKalibrantas の上流部に位 置するマラン効外に，インドネシャ政府によって, Kali konto, Karangkates の両ダムが建設されており，これら のダム周辺ならびに湛水池内に, 地すべり 発生の 素团 （地形的要因）を有する地区が数力所点在しているため これらの地区がダム湛水に伴ら「残存水王作用時」, あ るいは「水位上昇時」に，これらを直接の誘因としてす ベり出す可能性があるか否かを検討する必要を生じた。 このため,これらの地区における地すべり発生の可能性 (危険度合い) をある程度予測し, これに対するもっと も効果的な防止工を決定する目的で，昭和 45 年 7 月から 翌46年 3 月の 8 カ月間にわたって, 地すべり踏査・調查 計画立案・ボーリング調査・計測調査等を実施し, これ らの結果に基づく, 地すべり機構の解析および防止工検 討を行なった。

その結果, 火山性台地に批ける゙ム湛水後の「残存水 圧作用時」, あるいは「水位上杽時」等に, 何パーセン 卜程度の安定度低下をきたすかの興味ある成果が得られ た。また，これに基づく防止工も現在実施されており， さらに, Kali konto 地区における防止工未着手部で，ダ ム水位上㜒に伴う地すべりがすでに発生しているので, これら地すべりの発生予知について, Kali konto 地区に 拈けるそれらを例として報告する。

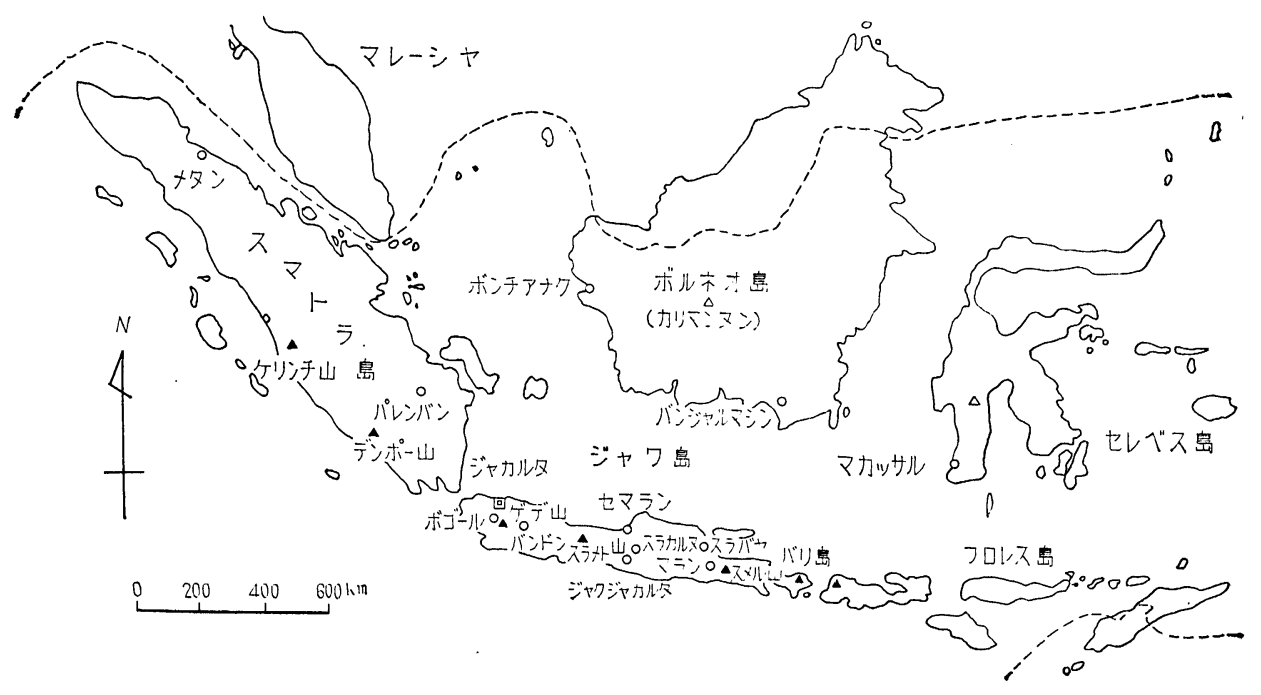

図-1 インドネシヤ主要部 


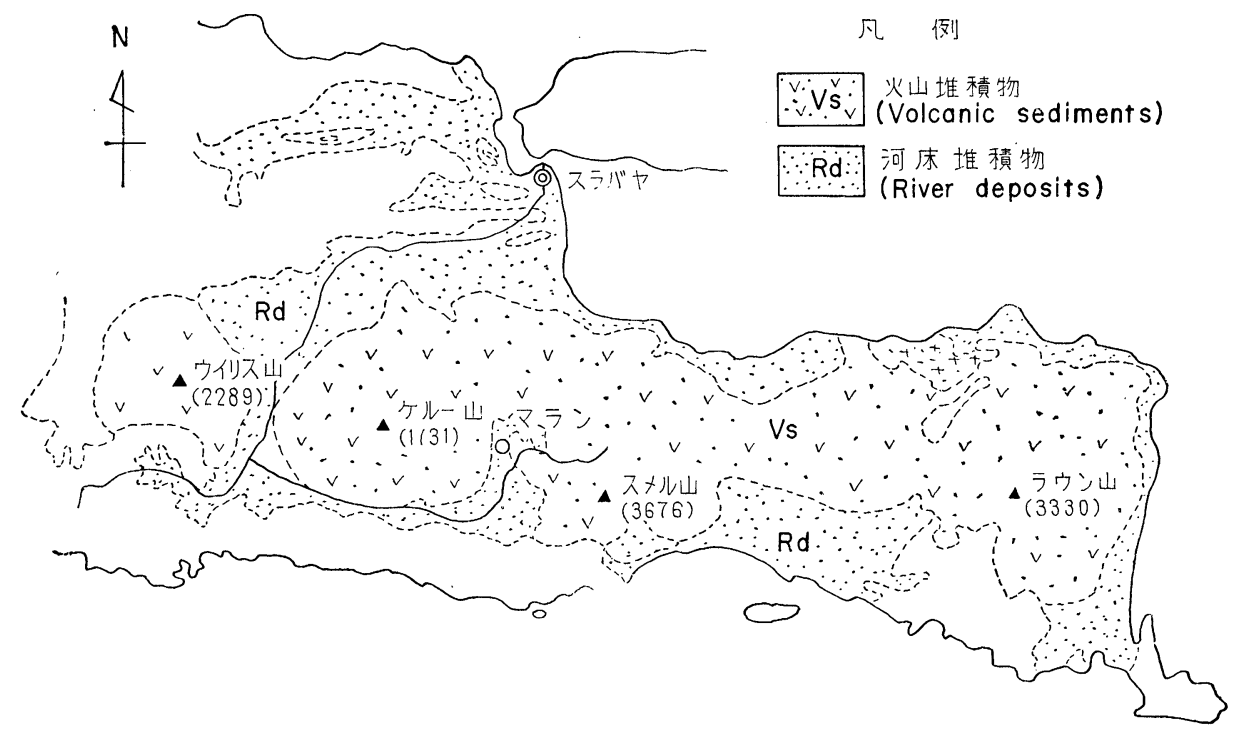

図-2 東部ジャワ地質概念図

\section{§2. 地形・地質の概要}

当Kali konto 地区の地形は，一般になだらかな丘陵性 台地から構成され，この台地内をほぼ東流する Kali konto およびその支川によって自然谷が形成されてい る。これらの河川は全般的に著しく Meander している ため, Meander 部では比較的に急傾斜の山地が形成さ れているが，直流部では緩傾斜の火山性台地がそのまま 残存している。ダムサイト付近の地形は図-3に示すごと く, 右岸側が比較的に急傾斜の山地, 左岸侧はわずか50 〜 $70 \mathrm{~m}$ 程度の幅にすぎない舌状丘陵地から構成されてお り, 元来綏傾斜の火山性台地であったものが，前述した Kali konto ならびにその支川によって侵食され，現在の 残丘が形成されたものと推察される。

地質状況は，いわゆる完全な意味での不動岩盤と考え られるそれは岩脈に起因する妿山岩 (An) のみであり, 当地区一帯には凝灭質砂岩 (Tss) ならびに 砂質凝灰岩 (STf), 扣よび凝灰質シルト (Tsi), 粘土 ( $\mathrm{Cl}$ ), ローム (Lo) 等の, いずれも火山灰に起因する火山性堆積物が 数 $\mathrm{m}$ 数 $10 \mathrm{~m}$ の層厚で広範囲に分布している。したがっ て，地質状沉としては全般的に藷しく不良であり，ダム の基礎としてはもとより，地すべりに対する明確な不動 岩盤となり得るものは前述した安山岩のみといえよう。 しかしながら，調查結果によって判明した固結度の低い 凝灰質砂岩ならびに砂質凝灰岩の両者, および凝灰質シ ルトの一部は，前述のごとく岩質良好とはいいがたい が，一応の基盤岩 (不動岩) としては利用し得るようで ある。

\section{§3. 地すべりの概要}

当地区の地すべりは図-3に示すごとく, 左岸側で $\mathrm{A} \sim$ Dの 4 力所, 右岸侧では $\mathrm{E} \sim \mathrm{F}$ の 2 力所, 計 6 力所にそ れが分布し，いずれも地形・地質的に地すべり発生の素 因を有している。したがって，これら 6 力所は湛水前に お壮る変動はともかくとして, 湛水後（特に高水位から 低水位への移行時）の変動発生が䏯念され，このらち， C, F 2 力所の地すべりは，その発生可能性が著しく大 なるものと判定される。以下, 前述の 2 地区 (C, F) について，それぞれの地すべり機構を概述する。

\section{$3.1 \mathrm{C}$ 地 区}

当地区は I，II の 2 ブロックに細分されるようであ り，図-4に示すごとく，いずれも第 1 次すべりはすべり 面深 $5 \mathrm{~m}$ 前後の表犀すべり，符 2 次すべりは I ブロック がすべり面深10m前後の大円すべりであるのに対し，II ブロックは $15 \mathrm{~m}$ 前後の円弧すべり（地質条件の相異に よる), 第 3 次すべりは両者ともすべり面深 22 25m 程 度の樑層すべりと考えられ，ダム湛水に伴う地下水位上 昇(間隙水圧増大) を直接の誘因としてすべり出す可能 性が大である。

\section{$3.2 \mathrm{~F}$ 地 区}

当地区も C地区と同様 I , II の 2 ブロックに細分さ れ，図-5に示すごとくいずれも第 1 次〜第 3 次の 3 すべ り面存在が考虑される。すなわち，I ブロック（F-I 測線）は下部川側より第 1 次すべり $\left(R_{1}=110.0 \mathrm{~m}, \theta_{1}=\right.$ $\left.30^{\circ} 30^{\prime}\right)$ ，第 2 次すべり $\left(R_{2}=120.0 \mathrm{~m}, \theta_{2}=33^{\circ} 00^{\prime}\right)$, 第 3 次すべり（第 1 次・第 2 次括よび直線部の複合すべ り）の 3 すべり面, IIブロック（F一II測線）では同じ く下部川側より第 1 次すべり $\left(R_{1}=119.0 \mathrm{~m}, \theta_{1}=38^{\circ} 45^{\prime}\right)$, 符 2 次すべり $\left(R_{2}=164.2 \mathrm{~m}, \theta_{2}=33^{\circ} 30^{\prime}\right)$ ，第 3 次すべ り（第 3 次円弧, $R_{3}=127.0 \mathrm{~m}, \theta_{3}=42^{\circ} 30^{\prime}$ と第 2 次円 
地すべり.Vol. 8, No. 1 (通巻 25号)

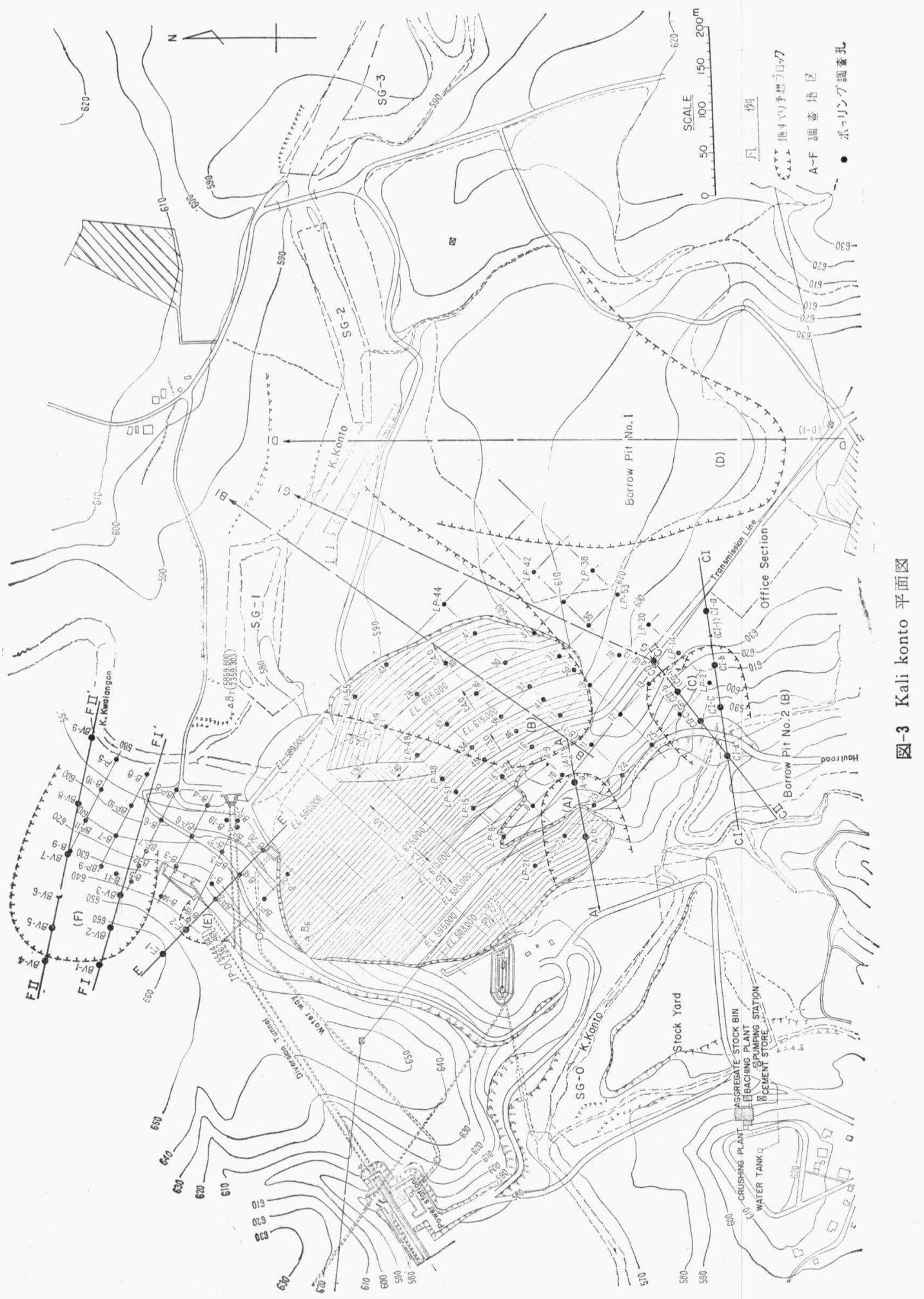




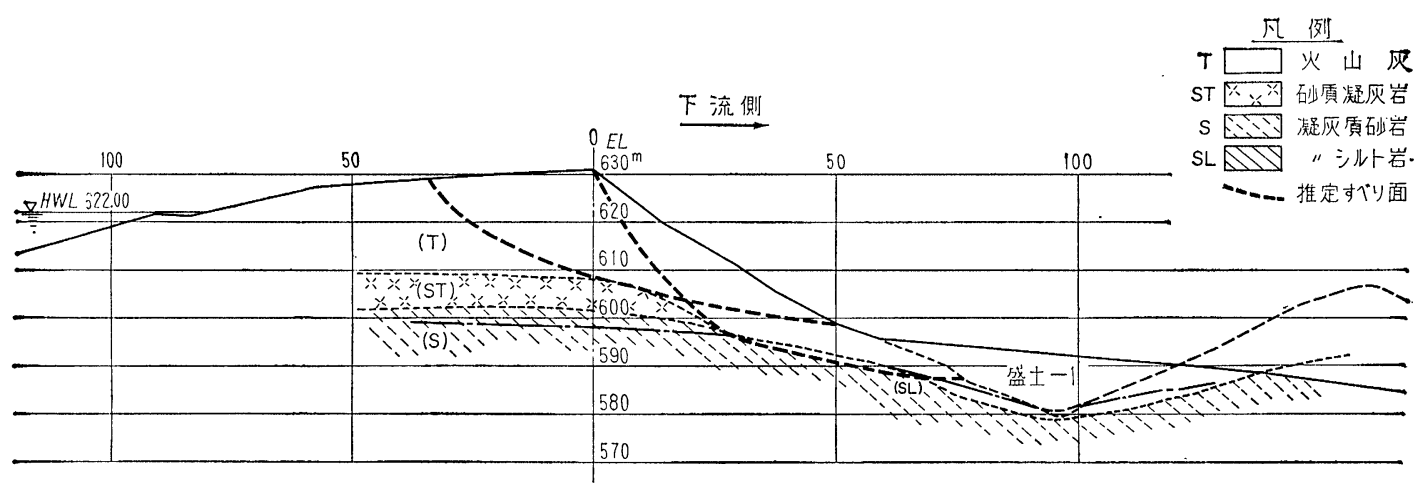

図-4 C 地区断面図（II測線）

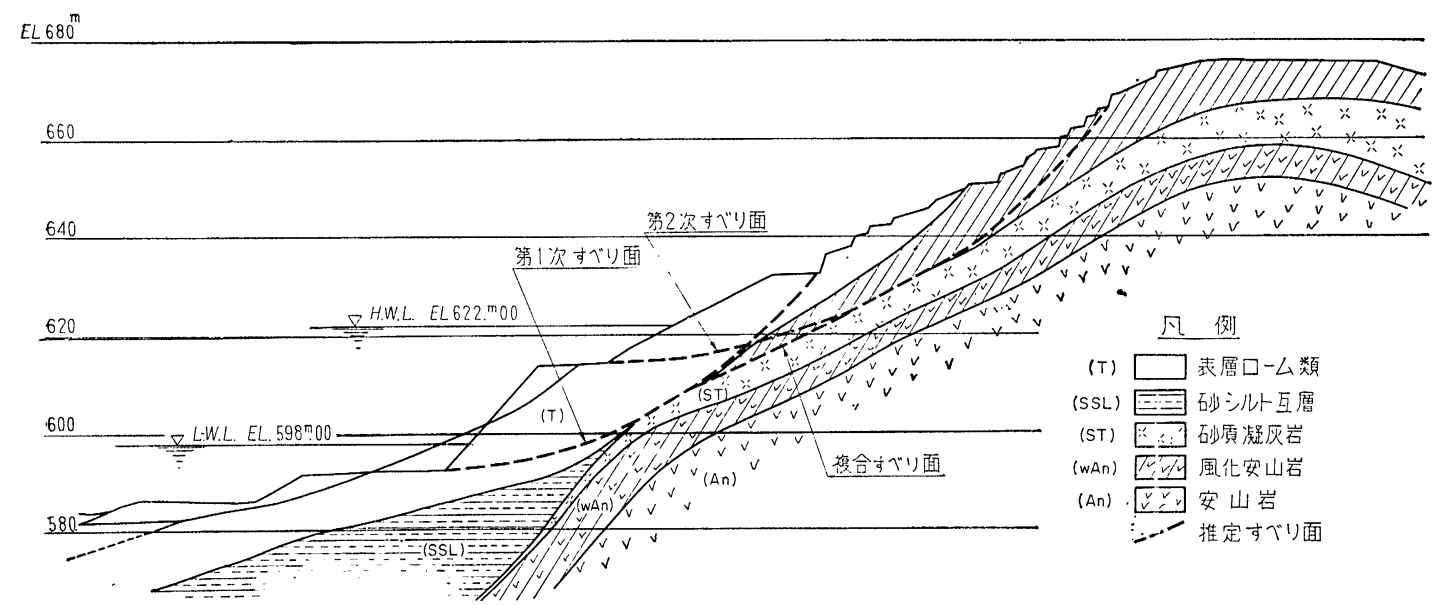

図-5 F 地区地質断面図

弧の複合すべり）の3すべり面の存在がそれぞれ考慮さ れ，すべり面の平均深は両ブロックとも第 1 次すべりが $15 \mathrm{~m}$ 前後, 第 2 次すべりは10〜 $15 \mathrm{~m}$, 第 3 次複合すべり は15 17 $\mathrm{m}$ 程度で，いずれも比較的地下深部にすべり面 を有しているよらであり，ダム湛水後に打ける残存水圧 作用時（高水位から低水位への移行時）に変動する可能 性が大である。

\section{§4．地すべり斜面の安定度}

一般に地形・地質的要因から地すべり発生の素因を有 すると判定される地区に打いて，人為的な環境変化（道 路建設, 宅地造成, ダム湛水等) を生ぜせしめる場合 は，その斜面の安定度が原地形のそれに比して，環境变 化後に何パーセント変化するかを検討し，その低減率が 5 10\%を超過する場合は地すべりが発生するものと予 測し，この 5 10\%の変化率を限界安全率*と称してい る。すなわら, 表-1に示すごとく昭和 42 年に発生した大 迫ダムの崩積土すべり（付替え道路建設に伴ら斜面末端
カットが直接誘因）から昭和45年の横須賀市武山地区に 打ける表層すべり（宅地造成に伴う頭部盛土）に至る多 数の実例から代表的な例を抽出してその限界安全率を検 討してみると，ほぼ 5 10\%の間にそれが集中して拉 り，本表に示す以外の他の実例についてもその傾向が大 である。

したがって，調査の対象となる地区に拈ける原地形あ るいは現状地形等, いわゆる自然状態下の安定度を $F S_{0}$ $\geqq 1.0$ と仮定して地すべり土塊の強度（ $c$ および $\phi)$ を土 質試験結果をも参考として経験的**に決定し, その決定 值に基ついて環境变化時に対する安定度を検討する。

以下，§3で詳述したC，F 2 地区について，自然状 態，水位上昇時，残存水圧作用時に扎けるそれぞれの安 定度を検討する。なお，土塊の湿潤密度 $\gamma_{t}$ は土質試験の 結果を採用して, いずれの地区についても $1.4 \mathrm{t} / \mathrm{m}^{3}$ と し, 粘着力 $c$ ならびに摩擦角 $\phi$ は, 土質試験結果と図 -4 に示す $c \sim \phi$ 関係図から，それぞれのすべりに対する現 状 (現地形) での安定度がいずれも $F S \geqq 1.0$ となる数

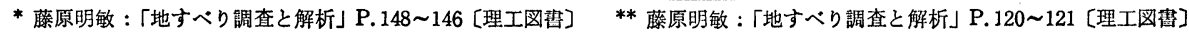


地すべり Vol. 8, No. 5 (通巻 25号)

表-1 限界安全率一覧表

\begin{tabular}{|c|c|c|c|c|c|c|c|}
\hline \multirow{2}{*}{$\begin{array}{c}\text { 調查地区 } \\
\text { (府県) }\end{array}$} & \multicolumn{2}{|c|}{ 土塊強 度 } & \multicolumn{2}{|c|}{ 安 定 } & \multirow{2}{*}{ 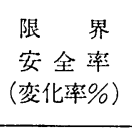 } & \multirow{2}{*}{ 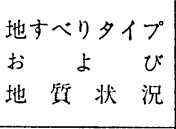 } & \multirow{2}{*}{$\begin{array}{cccc}\text { 㨁 } & & \text { 接 } \\
\text { 㧍 } & \text { よ } & \text { び } \\
\text { 阔 } & \text { 接 } & \text { 誘 } & \text { 因 }\end{array}$} \\
\hline & $\begin{array}{c}c \\
\left(t / m^{2}\right)\end{array}$ & $\begin{array}{c}\phi \\
(\tan \phi)\end{array}$ & $\begin{array}{c}\text { 原地 形 } \\
\left(\mathrm{FS}_{0}\right)\end{array}$ & $\begin{array}{l}\text { 地すべり } \\
\text { 登生 時 } \\
\left(\mathrm{FS}_{0}^{\prime}\right)^{\prime}\end{array}$ & & & \\
\hline $\begin{array}{l}\text { 大 迫 } \\
\text { (奈 良) }\end{array}$ & 1.5 & $\begin{array}{l}23^{\circ} 50^{\prime} \\
(0.442)\end{array}$ & $\begin{array}{l}1.109 \\
(1.00)\end{array}$ & $\begin{array}{c}0.985 \\
(0.888)\end{array}$ & 11.20 & $\begin{array}{l}\text { 崩穔土すべり } \\
\text { むニ混り磼 } \\
\text { および粘板岩 }\end{array}$ & 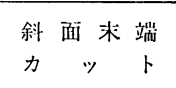 \\
\hline $\begin{array}{lr}\text { 蓩 } & \text { 秒 } \\
\text { (群 } & \text { 馬) }\end{array}$ & 0.5 & $\begin{array}{l}19^{\circ} 50^{\prime} \\
(0.361)\end{array}$ & 1.001 & 0.945 & 5.60 & 火山砝㻺物 & $"$ \\
\hline $\begin{array}{l}\text { 織 } \\
\text { 篮 }\end{array}$ & 1.2 & $\begin{array}{l}11^{\circ} 40^{\prime} \\
(0.206)\end{array}$ & $\begin{array}{l}1.015 \\
(1.00)\end{array}$ & $\begin{array}{c}0.924 \\
(0.910)\end{array}$ & 9.00 & $\begin{array}{l}\text { 表䖉すべり } \\
マ \quad \forall \quad \text { 類 }\end{array}$ & " \\
\hline $\begin{array}{l}\text { 知 } \\
\text { (変 知) }\end{array}$ & 2.0 & $\begin{array}{l}7^{\circ} 20^{\prime} \\
(0.129)\end{array}$ & $\begin{array}{l}1.039 \\
(1.00)\end{array}$ & $\begin{array}{c}0.994 \\
(0.957)\end{array}$ & 4.30 & $\begin{array}{l}\text { 崩稍土すべり } \\
\text { 磁混りシルト }\end{array}$ & " \\
\hline $\begin{array}{ll}\text { 大 } & \text { 利 } \\
\text { (福 } & \text { 島) }\end{array}$ & 2.0 & $\begin{array}{l}13^{\circ} 30^{\prime} \\
(0.240)\end{array}$ & 1.003 & 0.946 & 5.70 & $\begin{array}{c}\prime \prime \\
\text { 磎混りローム }\end{array}$ & " \\
\hline $\begin{array}{lr}\text { 消 } & \text { 石 } \\
\text { (長 } & \text { 崎) }\end{array}$ & 1.5 & $\begin{array}{c}6^{\circ} 40^{\prime} \\
(0.117)\end{array}$ & $\begin{array}{l}0.988 \\
(1.00)\end{array}$ & $\begin{array}{c}0.933 \\
(0.935)\end{array}$ & 6.50 & 火山”确颜物 & $\begin{array}{l}\text { 頭部盛土 } \\
\text { お } \\
\text { 末端カッット }\end{array}$ \\
\hline $\begin{array}{l}\text { 赤 } \\
\text { （坂 } \\
\text { 緮 }\end{array}$ & 1.0 & $\begin{array}{l}15^{\circ} 10^{\prime} \\
(0.271)\end{array}$ & $\begin{array}{l}1.390 \\
(1.00)\end{array}$ & $\begin{array}{c}1.210 \\
(\text { 地卡水なし) } \\
(0.871)\end{array}$ & 12.90 & シルト斦砂 & $\begin{array}{ccc}\text { 斜 面 } 末 \text { 端 } \\
\text { 力 } & \text { ト }\end{array}$ \\
\hline $\begin{array}{l}\text { 下 } \\
\text { (大 }\end{array}$ & 1.0 & $\begin{array}{l}20^{\circ} 30^{\prime} \\
(0.374)\end{array}$ & 1.006 & 0.928 & 7.80 & 火山" & $\begin{array}{l}\text { 㣻 湛 水 } \\
\text { に伴方 } \\
\text { 残 存水圧 }\end{array}$ \\
\hline （商 知） & 2.0 & $\begin{array}{l}12^{\circ} 40^{\prime} \\
(0.225)\end{array}$ & 1.001 & 0.931 & 7.00 & 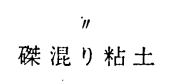 & $\begin{array}{c}\text { 斜面末 端 } \\
\text { 力 } \% \text { r }\end{array}$ \\
\hline $\begin{array}{l}\text { 武山 } \\
\text { (神奈川) }\end{array}$ & 0.8 & $\begin{array}{l}12^{\circ} 20^{\prime} \\
(0.219)\end{array}$ & 1.000 & 0.904 & 9.60 & $\begin{array}{l}\text { 表㢄すべり } \\
\text { 砂買シルト }\end{array}$ & 頭 部 盛 土 \\
\hline 均 & 1.35 & $\begin{array}{l}14^{\circ} 30^{\prime} \\
(0.258)\end{array}$ & 1.000 & 0.921 & 7.90 & & \\
\hline
\end{tabular}

值, すなわち, $c=1.0 \sim 2.0 \mathrm{t} / \mathrm{m}^{2}, \phi=9^{\circ} 00^{\prime} \sim 18^{\circ} 40^{\prime}$ の 值 (C地区 : $c_{1}=1.0 \mathrm{t} / \mathrm{m}^{2}, \quad \phi=9^{\circ} 00^{\prime}, \quad c_{2 \sim 3}=2.0 \mathrm{t} / \mathrm{m}^{2}$, $\phi_{2 \sim 3}=15^{\circ} 40^{\prime}$, F 地区 : $\left.c=2.0 \mathrm{t} / \mathrm{m}^{2}, \phi=18^{\circ} 40^{\prime}\right)$ を決定 した。また，安定計算に使用した式は，単純円弧すべり が（1）式, 複合すべり（2 円弧と直線）は（2）式であ る。

$$
\begin{aligned}
& F S= \frac{\tan \phi \sum(W \cos \theta-\mu)+c \sum l}{\sum \sin \theta} \ldots \\
& F S=\left[\frac{r_{1}}{a_{1}}\left(\tan \phi \sum_{A}^{B} W \cos \alpha+c \sum_{A}^{B} l\right)\right. \\
&+\frac{r_{2}}{a_{2}}\left(\tan \phi \sum_{C}^{D} W \cos \alpha+c \sum_{C}^{D} l\right) \\
&\left.+\tan \phi \sum_{B}^{C} W \cos \alpha+c \sum_{B}^{C} l\right] \\
& /\left[\frac{r_{1}}{a_{1}} \sum_{A}^{B} W \sin \alpha+\frac{r_{2}}{a_{2}} \sum_{C}^{D} W \sin \alpha\right. \\
&\left.+\sum_{B}^{C} W \sin \alpha\right] \ldots \ldots .
\end{aligned}
$$

ただし，l：すべり面の長さ $(\mathrm{m})$

$W \sin \theta:$ 各細片に批けるせん断応力 $\left(\mathrm{t} / \mathrm{m}^{2}\right)$ $W \cos \theta:$ 垂直応力 (" ) $c$ ：地すべり土塊の粘着力 ( " ) $\phi ：$ 地すべり土塊の内部摩擦庙（度）

$\mu$ : 間 隙 水 圧 $\left(\mathrm{t} / \mathrm{m}^{2}\right)$

$r_{1}, r_{2}:$ 弧の半径 $(\mathrm{m})$

$a_{1}, a_{2}:$ 円の中心ら土圧作用点までの距離

(m)

$W:$ 各スライスの重量 $(\mathrm{t})$

$\alpha$ : 各スライスのすべり面が水平面とな 寸的 (度)

つぎに, 残存水圧作用時(水位低下時)に対しては( 3 ): 式によってそれぞれの安定度を検討する。

$$
F S=\frac{\tan \phi \sum(W \cos \theta-\mu)+c \sum l+P_{W}}{\Sigma W \sin \theta}
$$

この場合,

$$
\begin{gathered}
\mu: \text { 満水時 }(\mathrm{HWL}) \text { の間隙水圧 }\left(\mathrm{t} / \mathrm{m}^{2}\right) \\
P_{W}: \text { 低水時 }(\mathrm{LWL}) \text { の押さえ水圧 }(" \text { " })
\end{gathered}
$$

なお，複合すべりについても $P_{W}$ は同様としてあつが 5。

\section{1 自 然 状 態}

前述の(1)〜(2)式によって， C，F両地区に打けるそ れぞれの安定度を检討すると，表-2のごとくとなる。 以上のごとく，C地区では I ブロックの第 1 次すべ 
表-2 自然状態の安定度

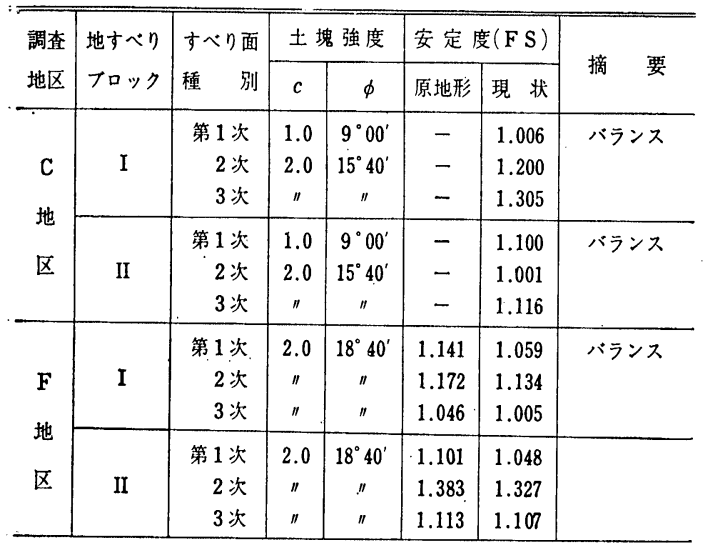

り， II ブロックの第 2 次すべり，F 地区では I ブロック の第 3 次 (複合) すべりが，現状でいずれもほぼバラン スの状態にあり，その他のすべりはかなり妿定側にある ものと考えられる。

\section{2 タ厶水位上昇時}

一般に，ダム水位上暑時におけるる湛水池内の地すべり 斜面は, ダム湛水に伴ら押さえ水圧 $P_{W}$ の作用によって, その努定度はより增加するのが通例であるため, 聍水池 内の F 地区についてはダム水位上昇時についての検討は 䍒施しない。しかしながらC地区はダム湛水池から火山 性台地のやせ尾根をへだてた下部側に位置しているた め，㵐水防止を目的とする Rim grout は実施されてい るとはいらものの, ダム満水時 (HWL 622.00m) には ダムからの浸透水がかなり供給されるものと考え极ばな らず，その量いかんによっては地下水位が異常に上晶 (間隙水圧の上昇) することになる。

したがって，図-4に示すごとく道路建設に付随して笑 施が予定されているC 地区未端部の盛土（盛土一1）完 了後の状態について, 地下水をなったく考慮しない場合 (盛土時), つぎに, 地下水位の状態を平常水位（現状の 水位), 中間水位 (常識的に考えられる上昇水位), 最悪 時の異常水位 (HWL 以下は全水浸) の 4 種に区分し て，それぞれの发定度を検討すると，表-3のごとくとな る。

以上のごとく, 異常水位時はともかくとして, 中間水

表-3 地下水の状態による安定度

\begin{tabular}{|c|c|c|c|c|c|c|}
\hline \multirow{2}{*}{$\begin{array}{l}\text { 地すへリ } \\
\text { フロック }\end{array}$} & すべり面 & \multicolumn{4}{|c|}{ 盛土工の安定度 (F S ) } & \multirow{2}{*}{ 摘 要 } \\
\hline & 種 別 & 盛土時 & 平常水位 & 中閒水位 & 異常水位 & \\
\hline \multirow{3}{*}{ I } & 第 1 次 & 2.083 & 1.668 & - & 1.253 & \\
\hline & 2 次 & 1.807 & 1.532 & - & 1.128 & \\
\hline & 3 次 & - & - & 1.108 & 0.883 & \\
\hline \multirow{3}{*}{ II } & 第 1 次 & 2.487 & 1.871 & - & 1.320 & \\
\hline & 2 次 & 1.251 & 1.148 & 0.758 & 0.681 & 不安定 \\
\hline & 3 次 & - & $-\cdot$ & 0.820 & 0.640 & " \\
\hline
\end{tabular}

位時においてもC地区II測線における第 2 次, 第 3 次両 すべりの安定度は $F S=0.76 〜 0.82$ を示すにすぎず，明 らかに不安定となることが判明した。したがって，当地 区の地すべりに対しては， I测線の第 2 次，符 3 次両す ベりの安定度を少なくとも $F S \geqq 1.00$ とするような防止 工の検討が必要となる。

\section{3 ダム水位低下時（残存水圧作用時）}

ダム水位が満水位 (HWL) 方ら低水位 (LWL) へ移 行する場合, ダム湛水池内に位置する地すべり斜面へ供 給された満水特の地下水は, ダム水位の低下速度よりか なり遅れて排出される可能性が大であり，このため満水 位時の地下水位がそのまま残存する場合も当然考えられ る。

したがって，この残存水圧が作用する場合の F 地区の 岁定度を前述した（3)式によって検詩してみると，表-4 のごとくとなる。

表-4 残存水压作用椨の安定度

\begin{tabular}{|c|c|c|c|c|c|c|}
\hline \multirow{2}{*}{$\begin{array}{l}\text { 地すべり } \\
\text { フロック }\end{array}$} & すべり面 & \multicolumn{2}{|c|}{ 自然状態 } & \multicolumn{2}{|c|}{ 残存水圧作用時 } & \multirow{2}{*}{ 摘 要 } \\
\hline & 種別 & 原地 形 & 現 状 & 現 状 & $\begin{array}{l}\text { 安 定 度 } \\
\text { 低娍率\% }\end{array}$ & \\
\hline \multirow{3}{*}{ I } & 第 1 次 & 1.141 & 1.059 & 0.650 & 38.6 & 不安定 \\
\hline & 2 次 & 1.172 & 1.134 & 1.030 & 9.2 & " \\
\hline & 3 次 & 1.046 & 1.005 & 0.767 & 23.7 & $"$ \\
\hline \multirow{3}{*}{ II } & 第 1 次 & 1.101 & 1.048 & 0.671 & 36.0 & 不安定 \\
\hline & 2 次 & 1.383 & 1.327 & 1.037 & 21.9 & $"$ \\
\hline & 3 次 & 1.133 & 1.107 & 0.923 & 16.6 & $n$ \\
\hline
\end{tabular}

以上のように，F地区では残存水圧作用時の穴定度 が，I测線の符 2 次すべりを除いていずれも 17〜39\%も の妍定度低下を来たしており，完全に地すべりが発生す るものと预される。したがって, 当地区についても残 存水王作用時におけるそれぞれの努定度を少なくとも現 状 $(F S \geqq 1.00)$ にまで回復せしめる防止工の検討が必要 となる。

\section{§5. 防止工法の検討}

§4で検討したごとく，C・F 兩地区の地すべり斜面は 前者がダム水位上暑時にII測線第 2 次，第 3 次両すべり が不安定となり，後皆については残存水圧作用時にI・ II両测線とも不努定となることが判明した。したがっ て，ダム水位上昇に伴ら地下水位上昇（間陌水圧増大） に対するC地区第 2 次・第 3 次すべり (II測線), ダム 水位降下に伴ら残存水圧作用時に対する地区第 1 次〜第 3 次すべりについて，それぞれの丧定度を少なくとも $F S>1.0$ (原則的には $F S \geqq 1.2$ ) とするための防止工を 講ぜねばならない。以下，前述の安定度を確保するため の防止工を検討する。

\section{$5.1 \mathrm{C}$ 地 区}

当地区では図-6の盛土一 2 として示すように, EL. 


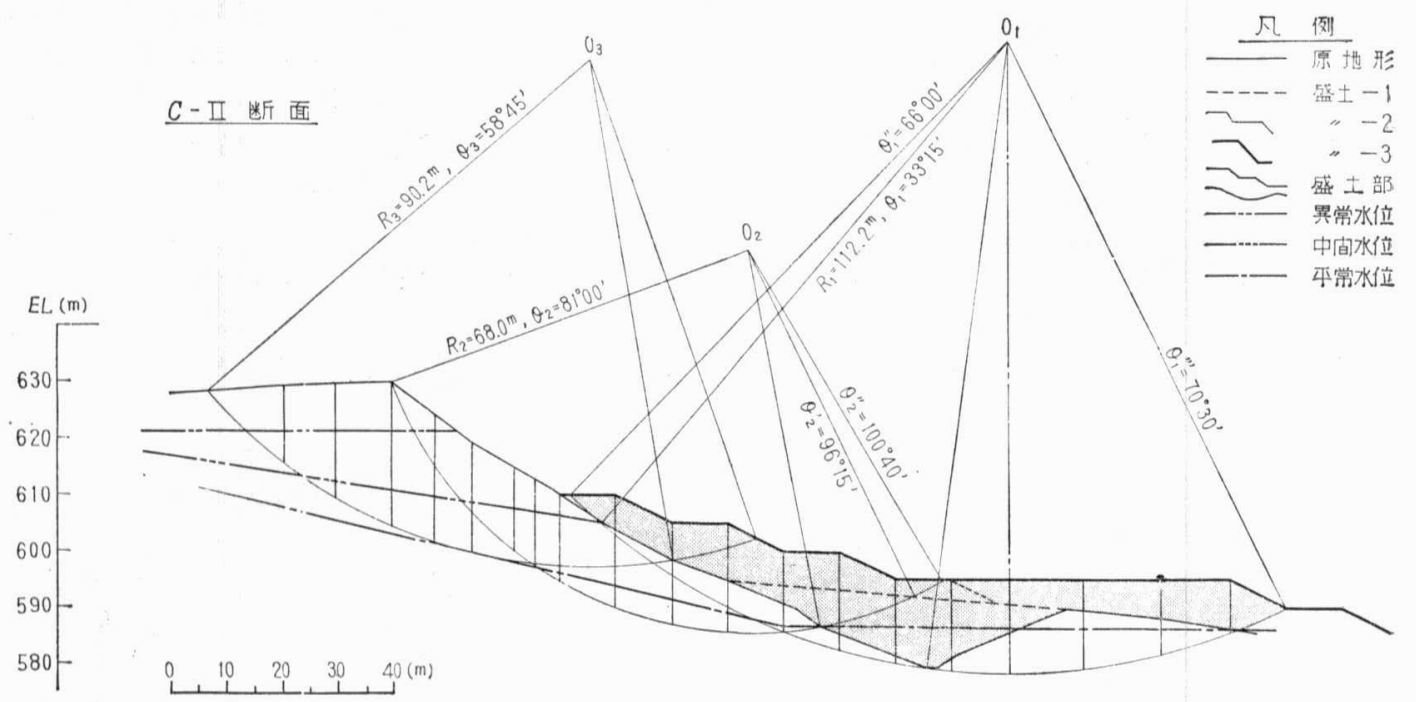

図-6 防止工断面図 (C-II測線)

$610.00 \mathrm{~m}$ から EL. $590.00 \mathrm{~m}$ 付近まで 2 割勾配 (台地幅 $10 \mathrm{~m}, 1$ 段のり高 $5 \mathrm{~m}$ ) の再盛土を実施し, 地形変換点 での排水工（明・暗渠排水路工）を充分施工して拈けば 少なくとも異常水位発生の事態は避けられるものと考兄 られ，常識的な中間水位までの水位上昇に留まるものと 想定される。また, 盛土一 2 と伴う新すべりの発生もほ とんど考觉られない。したがって，盛土一 2 にいての II 測線第 2 次 - 第 3 次両すべりの安定度を中間水位時に ついて検討すれば允分と考えられ，この場合の安定度は 第 2 次すべりのそれが $F S_{2}=1.142$, 第 3 次すべりは $F S_{3}$ $=1.113$ となり, 完全に安定となる。
なお，測線については図-4に示す盛土一1のみで充分 安定である。

\subsection{F 地 区}

当地区は地すべりの規模が著しく大であるため, 地す べり末端部に揦ける盛土（末端抵抗荷重付加，あるい は頭部地区の排土 (頭部荷重軽隇) 等の単一防止工のみ では所定の安定度増加を期待し得ない。したがって, 当 地区における防止工は末端部における押さえ盛土と頭部 地区に拈ける排土（段切り工）の併用工を採用し，ダム の最高水位 (HWL $622.0 \mathrm{~m}$ ) をも考虑して, 頭部土塊 カットは EL. $623.0 \mathrm{~m}$ 以上, 末端盛亡はそれ以下とする

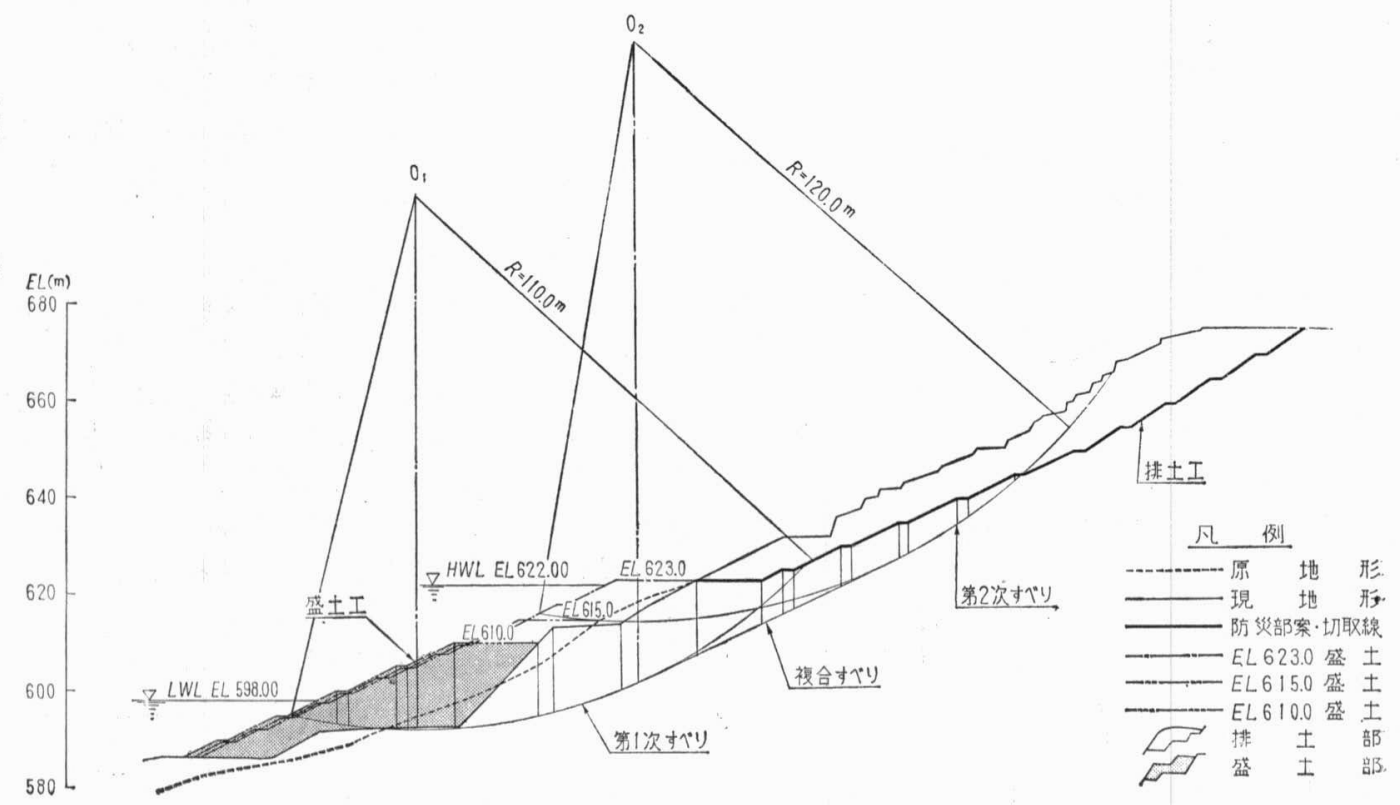

図-7 F 地区防止工断面図 
地すべり Vol. 8, No. 1 (通巻 25号)

表-5 防止工後の安定度

\begin{tabular}{|c|c|c|c|c|c|c|c|c|}
\hline \multirow{3}{*}{ プロック } & \multirow{3}{*}{$\begin{array}{l}\text { すべり面 } \\
\text { 種 別 }\end{array}$} & \multirow{3}{*}{$\begin{array}{l}\text { 残存水圧 } \\
\text { 作用時の } \\
\text { 安定 度 }\end{array}$} & \multicolumn{2}{|c|}{ 単独防止工 } & \multirow{2}{*}{\multicolumn{3}{|c|}{$\begin{array}{c}\text { 併 用 防j 止工 } \\
(カ ッ ト+\text { 盛土) }\end{array}$}} & \multirow{3}{*}{ 摘 } \\
\hline & & & \multirow{2}{*}{$\begin{array}{lll}\text { 頭 } & & \text { 部 } \\
\text { カ } & \% & \text { ト }\end{array}$} & \multirow{2}{*}{$\begin{array}{l}\text { 末端盛土 } \\
\text { (EL.610) }\end{array}$} & & & & \\
\hline & & & & & (E L.610) & 615 & 623 & \\
\hline \multirow{3}{*}{ I } & 第 1 次 & 0.650 & 0.742 & 0.868 & 1.014 & 0.950 & 0.882 & E L.610で灾定 \\
\hline & 2 次 & 1.030 & - & - & - & - & - & \\
\hline & 3 次 & 0.767 & 0.849 & 0.882 & 1.070 & 1.009 & 0.955 & $"$ \\
\hline \multirow{3}{*}{ II } & 第 1 次 & 0.671 & 0.707 & 0.967 & 1.076 & & & E L.610で安定 \\
\hline & 2 次 & 1.037 & - & - & - & - & - & \\
\hline & 3 次 & 0.923 & 0.993 & 1.061 & 1.153 & & & $"$ \\
\hline
\end{tabular}

防止工を検討する。

以下，頭部カットを図-7に実線で示すごとく実施した 場合 (case I), また，EL. $610.00 \mathrm{~m}$ まで盛土を実施し た場合 (case II)，ついで EL. $615.00 \mathrm{~m}$ まで盛土を実 施した場合 (case III), さらに, EL. $610.00 \mathrm{~m}$ まで盛土 した場合の地震時における安定度の検討を行ない, あわ せて頭部カットと末端盛土 (EL. 610，615，623m) の併 用工について，それぞれの地すべりに対する安定度を検 討し，その結果を表-5に示す。

なお，安定計算に使用する土塊強度は，地山部のそれ が自然状態で検討した $c=2.0 \mathrm{t} / \mathrm{m}^{2}, \phi=18^{\circ} 40^{\prime}$, 盛土部 のそれは土質試験結果の最低值である $c=4.0 \mathrm{t} / \mathrm{m}^{2}, \phi=$ $11^{\circ} 52^{\prime}$ とする。また，この安定度検討はもちろん残存水 圧作用時についてのそれであり, 地震時に拈ける盛土す ベりの検討は(4)式を使用した。

$$
F S_{e}=\frac{\tan \phi\left(\sum W \cos \theta-\mu-e \cdot \sum W \sin \theta\right)+c \sum l}{\sum W \sin \theta+e \cdot \sum W \cos \theta}
$$

たたし， $\quad e$ : 地震係数 (一般に $e=0.10 \sim 0.15$ )

以上のように I・I両ブロックとも図-6に示すような 頭部カットを実施した上で，EL. $610.00 \mathrm{~m}$ まで盛土を実 施すれば，第 1 次〜第 3 次すべりのいずれを問わず，そ の安定度は $F S=1.00$ となりほぼ安定する。

また，地震時に护ける盛土すべりについては，図-7に 示すごとく，I ブロックで盛土中を通る浅層すべり $\left(F S_{S}\right)$ ，盛土下面をすべり面とする深層すべり $\left(F S_{D}\right)$ の両者が考えられるが，地震係数を最大 0.15 とした場 合，それぞれの安定度は前者が $F S_{S}=1.336$, 後者は $F S_{D}=0.958$ となり, 後者に扎いて安全率が約 $4 \%$ 程度 不足する。しかしながら, 盛土の土塊強度は最低值の $c=4.0 \mathrm{t} / \mathrm{m}^{2}, \phi=11^{\circ} 52^{\prime}$ を使用しており, 実際にはそれ 以上の強度が期待され，かつ安定度の低减率も5\%（限 界发全率) 以内なので, 一応安全側と判定してもさしつ かえないものと思われる。

§6. むすび

前章までに詳述したごとく，セロレジョ（Selorejo）
ダム周辺における地すべり発生の可能性を有する（地形 ・地質的要因が地すべりの発生の素因となる）地区はA 〜 Fの 6 地区であり，このうち， C, Fの 2 地区は特に その可能性が大であった。したがって，この 2 地区につ いてそれぞれ現状（自然状態）での安定度を充分検討 し，ダム湛水に伴う地下水位上景時あるいは残存水圧作 用時等，いわゆる人為的な環境変化が自然状態に対して いかなる変化を与えるか，換言すれば人為的な環境変化 によって，それぞれの安定度が何\%損なわれるかを検討 した。その結果，C地区では盛土一1の場合にII ブロッ クの第 2 次, 第 3 次両すべりの安定度が中間水位時で 24 〜 18\%低下し，F地区では残存水圧作用時に I ・II ブロ ックのいずれを問わず，39～17\%もの安定度低下が考え られ, 両地区とも明らかに不安定になるものと判定され た。

したがって，C地区については図-6に示す末端押さえ 盛土工 (盛土一2, 約 $80,000 \mathrm{~m}^{3}$ ), F 地区については図 -7に示す頭部土塊カットならびにEL. $610.00 \mathrm{~m}$ までの末 端押さえ盛土工（頭部カット $90,000 \mathrm{~m}^{3}$, 盛土約 60,000 $\mathrm{m}^{3}$ ) の併用工を実施すれば，いずれのすべりについても その安定度が少なくとも $F S \geqq 1.00$ となり，ほぼ安定す るものと判定される。すなわち, 防止工施工後の安定度 は, C地区第 1 次すべりが $F S_{\mathrm{C} 1}=1.485$, 第 2 次すべり は $F \mathrm{C}_{\mathbb{I}_{2}}=1.142$ ，第 3 次すべり は $F \mathrm{C}_{\mathbb{I}_{3}}=1.113$ (い ずれも中間水位時）となり， $\mathrm{F}$ 地区のそれは第 1 次すべ りが $F S_{\mathrm{FI}_{1}}=1.014, F \mathrm{~F}_{I_{1}}=1.076$, 第 3 次すべりでは $F \mathrm{FF} \mathrm{I}_{3}=1.070, F \mathrm{FF}_{3}=1.153$ となり, いずれもその安 定度は $F S \geqq 1.0$ である。

以上の結果から, 当地区 (C, F 2 地区) の地すべり は図-8に示すような盛土, あるいは頭部カットと末端盛 土を実施すればほぼ完全に安定する。しかしながら，C 地区は常識的な中間水位時での検討, F地区は EL. $622.00 \mathrm{~m}$ より上部山側斜面では地下水位が存在しない （すべり面以下に存在？）場合の検傠であるため，これ 以上の水位上猆があった場合にはその安定度が当然損な

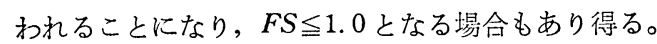

したがって，今後の問題としては既設ボーリング工 


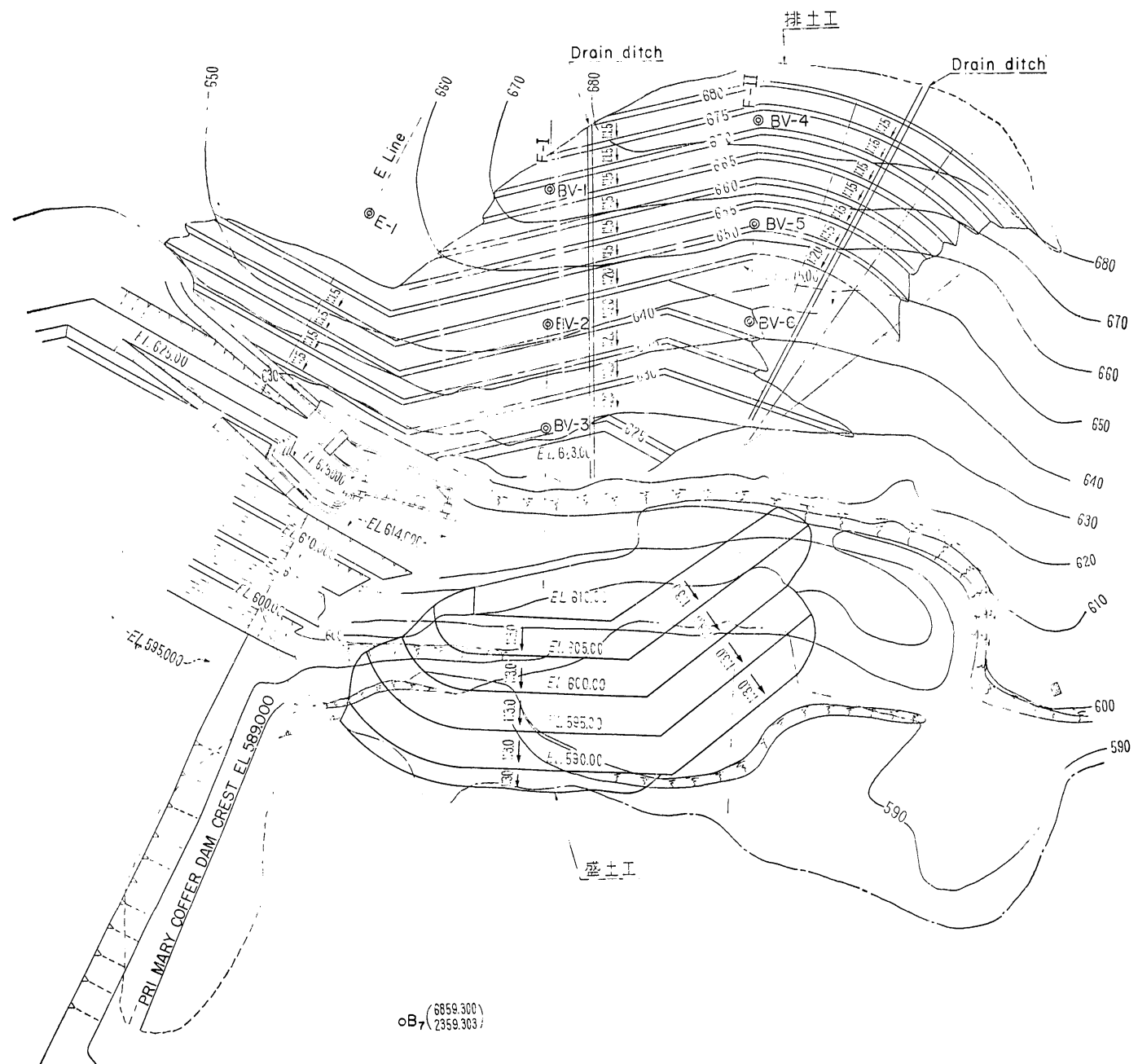

図-8 $\quad$ F 地区防止工平面园

（C，F 2 地区における調相ボーリング孔）における地下 水位の変化を少なくとも 1 力年程度継続して把握し，そ の結果によってそれぞれの尖定度を再度チェックするこ とが望ましい。
なお，盛上施工に際する地山の段比りカットならびに 脮渠による地下排水路教設, さらに盛土上面における表 面排水路敖設は当然実施しなければならない。 